\title{
Corporate environmental disclosure in the integrated reporting regime: The case of listed mining companies in South Africa
}

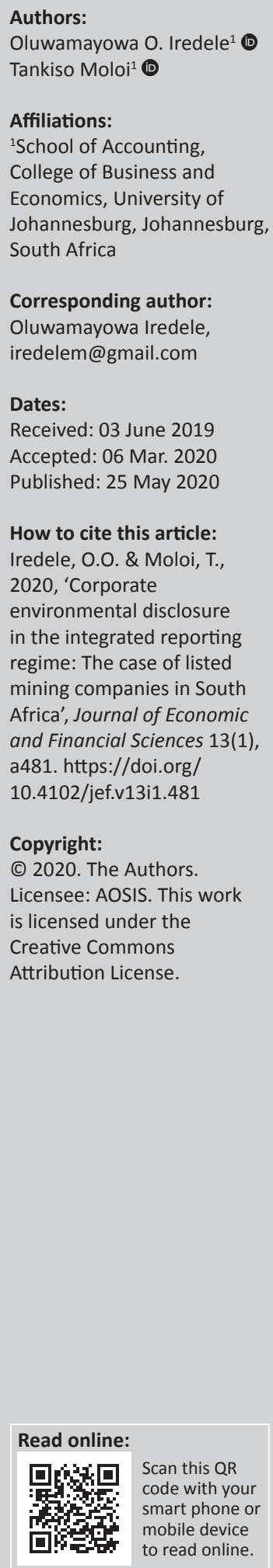

Orientation: The emergence and adoption of integrated reporting (IR) opens up a new agenda for improving the level of environmental disclosures, especially for listed companies. This study explores the environmental information disclosed by mining firms that are listed on the Johannesburg Stock Exchange (JSE) and in essence expects that the level of corporate environmental disclosure (CED) will improve compared to the periods prior to the mandatory requirement of IR.

Research purpose: This article examines the extent to which IR has influenced the level of CED among mining firms listed on the JSE. In addition, it determines variation in the level of CED on account of corporate governance attributes and firm-based characteristics.

Motivation for the study: The natural capital is an integral fundamental concept upon which the other five capitals depend. The negative impacts of mining activities on the environment necessitate that mining firms demonstrate higher levels of commitment in this regard.

Research approach/design and method: This study utilises data for the top 100 mining firms in the JSE between 2015 and 2018. This study obtained data on environmental and other variables through content analysis of the annual integrated and sustainability reports of sampled mining firms. Data analysis involves descriptive statistics and a one-way analysis of variance (ANOVA), with the aid of the Statistical Package for Social Sciences version 21.

Main findings: We found no improvement in the level of CED under the IR approach compared to earlier periods. Further, the study found that firm size and board size are associated with the level of CED.

Practical/managerial implications: If greater disclosure of information is preferable to less, policy-makers and regulators should give particular attention to environmental issues by extending the minimum regulatory requirements concerning the concept of the natural capital.

Contribution/value-add: This study is one of the first few studies that bring to fore the relevance of IR to CED in the South African mining sector.

Keywords: corporate environmental disclosure; integrated reporting; mining; South Africa; Johannesburg Stock Exchange.

\section{Introduction}

The framework by the International Integrated Reporting Council (IIRC) and the King Reports on Corporate Governance compulsorily mandate that all companies listed on the Johannesburg Stock Exchange (JSE) prepare a single set of report providing both financial and non-financial information in an integrated manner. The purpose of the report is to enhance shareholders' understanding of the firm and how it creates value over the short, medium and long terms (Barth et al. 2016; de Villiers, Rinaldi \& Unerman 2014; Melloni, Caglio \& Perego 2017). Part of the coverage of the framework comprises the fundamental concepts of the six capitals: the financial, manufacture, intellectual, human, social and relational and natural capitals (IIRC 2013a). The six capitals are the inputs to the organisation's business model. The framework, therefore, aims to provide insight on how the organisation interacts with the external environment and the capitals to create value for the firm.

Among the six capitals, the concept of the natural capital becomes extremely crucial because it borders on environmental issues and is the only concept that conforms to the United Nations (UN) goal of development which meets the needs of the present without compromising the ability of future generations to meet their own needs. In order to protect the environment from the negative 
impact of firms' activities, issues of environmental concern have become an integral part of the 17 sustainable development goals (SDGs) that member nations of the UN are expected to achieve by 2030 (UN 2018). Five of these goals relate directly to environmental issues, which include: clean water and sanitation (Goal 6), renewable energy (Goal 7), responsible production and consumption (Goal 12), climate action (Goal 13) and life on land (Goal 15). Therefore, in keeping with these goals, organisations are expected to disclose the intervention roles they play to mitigate the negative effect of their activities on the environment, particularly environmentally sensitive sectors such as mining. The integrated report has become the tool for achieving these goals in the South African context.

Prior to the mandatory requirement of integrated reporting (IR) for JSE-listed firms, environmental disclosure has been top on the agenda of corporate organisations in South Africa. It dates back to 1994 when there was need to help build public confidence in businesses, which led to the release of the first King report in 1994 known as King. This advocated for corporations to disclose non-financial information and adopt a balanced approach to business, involving all stakeholders (Institute of Directors [IoD] 1994; Moloi 2009). Subsequent King reports such as King II and III also widened the scope of reporting, requiring a holistic and integrated representation of the company's performance in terms of both its finance and sustainability and to include social and environmental dimensions (IoD 2002, 2009; Moloi 2009).

It was the release of the King III in December 2009 and later the King IV in 2016 that required that JSE firms adopt IR on the 'apply or explain' and the 'apply and explain' principles, respectively (IoD 2009, 2016; World Business Council on Sustainable Development [WBCSD] 2014). By implication, the principles require that firms improve their corporate environmental disclosure (CED) practices. The extent to which this has helped improve the level of CED, therefore, has created a gap in literature, which has not attracted sufficient attention in environmental disclosure research. It is in this context that this study aims to achieve the following objectives: (1) determine the extent to which IR has influenced the level of CED among mining firms listed on the JSE and (2) examine variations in the level of CED on account of corporate characteristics (firm size and profitability) and corporate governance attributes (board size [BS] and gender diversity). In achieving the study objectives, findings from this study are benchmarked with the results of previous studies conducted by Adagish (2009), Antonites and de Villiers (2003) and De villiers and Barnard (2000). This is done with the view to determine the level of CED in the present era of mandatory adoption of IR compared to the period before IR became mandatory.

Insightful contributions from this study can be summarised as three points. Firstly, it brings to the fore the relevance of IR to CED. This is important to assess the quality of IR released by mining firms with respect to environmental issues. Secondly, by examining the influence of BS and gender diversity on the level of CED, it highlights the effectiveness of corporate governance in promoting environmental responsibility in the mining sector. Then, theoretically, apart from the inherent nature of the mining sector and corporate governance attributes, it identifies contingent factors that influence the level of CED.

The rest of the article is structured in the following order. The next section provides a brief review of literature, theoretical framework and hypotheses development. This is followed by a discussion of the research method applied to the study. Then, the analysis and results presentation section follows, which is also followed by the discussion of findings and, finally, the conclusion of the study.

\section{Literature review, theoretical framework and hypotheses development}

The last two decades have seen an increasing quantum research in the area of environmental disclosure among researchers in the field of accounting (Adagish 2009; Akinlo \& Iredele 2014; Antonites \& De Villiers 2003; Deegan 2002; De villiers \& Barnard 2000; Gray 2002; Gray, Kouhy \& Lavers 1995; Owen 2008; Parker 2005; Unerman, Bebbington \& O'Dwyer 2007). This is precipitated by the rising spate of challenges arising from poor environmental performance of corporate organisations. The Exxon Valdez oil spill of 1989, AZote Fertilisant explosion of 2001 and the Volkswagen emissions scandal of 2015 are some of the global environmental issues calling for corporate concerns among firms (Association of Chartered Certified Accountant [ACCA] 2015; Daniel 2006).

Different frameworks exist for reporting environmental issues. While some have global relevance, others are countryspecific. The global reporting initiative (GRI) sustainability reporting guideline developed by GRI, the Social Accountability 8000 developed by Social Accountability International and the Organisation for Economic Cooperation and Development (OECD) Guidelines for Multinational Enterprises developed by OECD are some of the internationally recognised frameworks for environmental reporting. Among all these, the GRI guideline is the most definitive, widely accepted and commonly applied framework for environmental reporting globally (Hindley \& Buys 2012; Maguire 2011).

The GRI is a non-profit organisation that promotes economic, environmental and social sustainability and provides all companies and organisations with a comprehensive sustainability reporting framework that is widely used around the world. Although GRI was founded in 1997 in Boston, USA, the first version of the guidelines (G1) was launched in year 2000. Subsequently, others followed, namely G2 (2002), G3 (2006) with updated and complete versions, and (G3.1) in 2011. The G4, upon which this study is based, 
was launched in 2013 (GRI 2013a, 2013b), although it is gradually being replaced with the latest guideline known as the GRI Standards launched in October 2016.

According to the International Organisation of Supreme Audit Institutions (INTOSAI) (2013), there are also countryspecific guidelines for environmental disclosure. In the UK, the Accounting for Sustainability Project developed the Connected Reporting Framework for sustainability reporting, which encouraged both the private and public sectors to produce a sustainability report. In India, the Ministry of Corporate Affairs released Voluntary Guidelines on Social, Environmental and Economic Responsibilities of Business in July 2011, after considerable stakeholder consultation. In South Africa, the need to disclose financial and non-financial information to reflect the ability of organisations to create and sustain value in the short, medium and long term led to the adoption of IR. This is especially true in the South African mining sector, given its high social and environmental impact, as well as the significant contribution that the sector makes to the South African economy (Carels, Maroun \& Padia 2013).

\section{The importance of South Africa's mining industry}

According to the Mineral Council South Africa (2019), economic activity in modern-day South Africa has been centred on mining activities, their ancillary services and supplies. The country's stock exchange situated in Johannesburg was established in 1887, a decade after the first diamonds were discovered on the banks of the Orange River and almost simultaneously with the gold rush on the world-famous Witwatersrand. In many ways, South Africa's political, social and economic landscape has been dominated by mining, given that, for so many years, the sector has been the mainstay of the South African economy. Although gold, diamonds, platinum and coal are the most well-known among the minerals and metals mined, South Africa also has reserves of chrome, vanadium, titanium and a number of other minerals of lesser value. In 2018, the mining sector contributed R351 billion to the South African gross domestic product (GDP) and a total of 453,543 people were employed by this sector. The mining sector has, for many years, attracted valuable foreign direct investment to South Africa.

This major economic activity has positioned South Africa as the largest steel producer, and the country was ranked 25th and 24th among the world's top steel producers in 2017 and 2016, respectively (Organisation of Petroleum Exporting Countries [OPEC] 2017; World Steel Association 2018). Despite the huge contribution to the economy, the sector is recognised as the leading contributor to the apparent environmental neglect that contributes to climate change in Africa (Shaw 2012). This is evidenced by the country being ranked as the largest greenhouse emitter of carbon dioxide $\left(\mathrm{CO}_{2}\right)$ in Africa (International Energy Agency [IEA] 2015).

\section{The natural capital}

All organisations depend on various forms of capital for their success. According to the International Integrated Reporting Framework (IIRF), the capitals can be classified as financial, manufacture, intellectual, human, social and relational and natural capitals. The natural capital (which equates generally to an organisation's impact on the environment), being the focus of this study, is defined according to the framework as (IIRC 2013a):

All renewable and non-renewable environmental resources and processes that provide goods or services that support the past, current or future prosperity of an organization. It includes air, water, land, minerals and forests, biodiversity and eco-system health. (p. 12)

The development of sustainability reporting in the recent years has seen an increase in reporting with respect to natural capital. These are reported both quantitatively and qualitatively as specified in the GRI's 'Sustainability Reporting Guidelines'.

The natural capital has proven to be the basis for other capital. This is because it is the basis not only for production but also of life itself. Human well-being arises from the use of a combination of types of capital: social capital, human capital and built capital, but these are all based on natural capital. Human societies feed on natural capital, withdrawal and use different kinds of ecosystem services (Forum for the Future 2009).

\section{Interaction between integrated reporting and corporate environmental disclosure}

Although sustainability reporting is an intrinsic element of the integrated report, which has led to the increase in disclosure of environmental information, it has been criticised for obvious reasons. According to IIRC (2013), it is less likely to focus on the connectivity between various capitals or the strategic relevance of the capitals to value creation. It is also more likely to include disclosures that would not be the material for inclusion in the integrated report. However, because natural capital affects stakeholders' perceptions of the organisation in such a way that it has a significant business consequences, such as to strengthen or weaken customers' demands or affects the organisation's licence to operate, the impact of the natural capital is considered materially worthy of being disclosed in the integrated report. It is on this basis that the disclosure of environmental information forms an integral part of the integrated report released by firms on the JSE.

\section{Theoretical framework}

Three main theories provide theoretical underpinnings for this study; namely legitimacy, stakeholder and contingency theories. The legitimacy theory is relevant because it supports the reporting of environmental information as a way of legitimising the operations of the firms. Deegan (2002) posits 
that the need to ensure that organisations operate within the bounds and norms of society is a major drive for CED. In line with the stakeholder theory, there exists a coalition of stakeholders who are interested in the affairs of the firm, and the success of the firm is dependent upon the successful management of all the relationships with and among its stakeholders. An integrated report, therefore, serves as the vehicle for disseminating information that is relevant to the stakeholders. In addition to the two theories above, the application of the contingency theory explains why firms may differ in the level of environmental information disclosed within the integrated reports. Firms may be subject to the same level of regulatory requirements such as the mandatory compliance with IR by all firms listed on the JSE, but respond to this regulation differently based on individual firm-based characteristics in line with the contingency theory. This is because the initiative to disclose environmental information is dependent upon a number of factors, which varies across organisations. This study predicts that the level of CED is influenced by two firm-based characteristics (profitability and firm size) and two corporate governance attributes (BS and gender diversity) (Bhattacharyya 2014).

\section{Hypotheses development \\ Firm size}

Prior studies (Bhattacharyya 2014; Deegan \& Gordon 1996; Ho \& Taylor 2007; Mishari \& Abdullah 2014; Mohammed \& Tamoi 2006) revealed that company size, as measured by total assets, provides an explanation on the variability of environmental disclosure among corporate organisations. A possible explanation for the perceived influence of firm size on the level of CED is that large firms have a greater need to disclose in order to satisfy the information needs of their large pool of stakeholders. Mostly, the practices of large firms are more noticeable and, thus, prone to more scrutiny by regulatory authorities. Contrary to this position, Demir and Bahadir (2014) and Wallace and Naser (1995) suggest that smaller firms are more likely than larger firms to feel that greater disclosure would be detrimental to their competitive position. In view of the debate above, this study hypothesises that:

H1: Firms differ significantly in CED on account of variation in size.

\section{Profitability}

Producing high-quality integrated reports, which provide detailed information on the environmental performance of firms, has its associated costs. For firms to fare well in this regard, sufficient financial resources are required, and only profitable firms can afford this. It is in line with this that studies have found a positive association between profitability and level of CED (Cheng \& Courtenay 2006; Mishari \& Abdullah 2014). On the other hand, environmental disclosure has been associated with huge financial implications, thus leading to a negative relationship with CED (Andrikopoulos \& Kriklani 2013; Ho \& Taylor 2007). Other studies have also found no significant association between these two variables
(Adams 2002; Demir \& Bahadir 2014). This study, therefore, is poised to establish the association between the two variables in the context of the mining firms in South Africa. This led to the formulation of the second hypothesis for this study:

H2: Firms differ significantly in CED on account of variation in profitability.

\section{Board size}

Previous studies in the mining industry (Trireksani \& Djajadikerta 2016) and studies conducted on other fields (Ofoegbu, Odoemelam \& Okafor 2018) revealed that varied composition of the board is perceived to be capable of influencing the extent to which corporate entities disclose their activities in protecting the environment. This is because the complexity of the information relating to environmental and other components that form the content of the integrated report demands intellectual competence. Hence, a varied board that has an appropriate mix of experts in relevant disciplines is crucial to this. Contrary to this, Lipton and Lorsch (1992) opine that a small-sized board might be more effective than large boards because of the difficulty in reaching a consensus in the latter. Their study states that divergent views may exist within a large board, which may reduce effectiveness. This study attempts to establish such relationships in the case of the mining sector in South Africa. This leads to the following hypothesis:

H3: Firms differ significantly in CED on account of variation in board size.

\section{Gender diversity}

Certain inherent qualities in women, such as sensitivity and transparency, influence the communication style of women and cause them to have a better relationship with all the stakeholders of the company (Bear, Rahman \& Post 2010). Including them on the board, therefore, can allow the company to be more willing to disclose more information about what is happening in the company. In addition, women think differently compared to men, and they have a different work ethic. This leads to the formulation of a testable hypothesis to confirm this assertion:

H4: Firms differ significantly in CED on account of variation in gender diversity.

\section{Research method}

This is a quantitative research comprising a population of 27 companies in the mining sector of the JSE. According to Ernst \& Young (EY) (2018), as on 31 December 2018, only eight out of the 27 mining companies made it to the list of the top 100 firms in JSE based on market capitalisation, and these form the sample for this study. The top 100 companies were the focus of the study because they represent $93 \%$ of the market capitalisation of the JSE (EY 2018). The activities of these companies influence the practice of other companies and can have greater impact on the capital market and the economy as a whole. The study focuses on the mining sector because companies in this sector have a much greater environmental 
impact than other industrial companies do. The mining companies in the top 100 were considered appropriate because they attract greater attention from investors. As a result, there is need for greater accountability through the disclosure of environmental information to investors and other users of the integrated reports, an expectation that may not be required of mining firms that are not listed.

Data were obtained from the annual integrated and sustainability reports of these eight mining firms for a 4-year period from 2015 to 2018, and this gives rise to total firm-year observations amounting to 32 . All the eight mining firms qualify to the list of the top 100 firms on the JSE for the sample period (see Appendix 1, Box 1-A1). The small sample size is in line with previous studies on corporate social responsibility in the mining industry, for example, the study conducted by Dube and Maroun (2017). The data analysis approach applied in this study is therefore informed by this sample size. The year 2015 was chosen as the base period because the International Integrated Reporting Council (IIRC) released the IR framework in December 2013, and the Integrated Reporting Committee (IRC) of South Africa endorsed it in March 2014. Effectively, the year 2015 may be regarded as the first full year of its adoption. To date, both the King Reports on Corporate Governance and the IIRC Framework became a listing requirement for all companies listed on the JSE.

The study employed the content-analysis approach as used in previous studies (Deegan \& Gordon 1996). Data on environmental reporting were based on a checklist covering 10 environmental performance variables derived from the GRI G4 framework, which are materials, energy, water, biodiversity, emissions, effluents and waste, products and services, compliance, transport, overall supplier environmental assessment and environmental grievance mechanisms (see Appendix 1, Figure 1-A1). The quality of information reported was assessed using a five-point rating scale as done in previous studies (Zyl 2013), and this ranged from 1, where the item was 'just mentioned' to 5, for 'significant disclosure' (see Appendix 1, Table 1-A1). The scale was developed within the GRI G4 principles for defining report quality such as balance, comparability, accuracy, timeliness, clarity and reliability (GRI 2013b). The maximum score obtainable by a firm from the 10 environmental indicators using the five-point rating scale was 50 .

Furthermore, the variability in CED was determined in relation to four characteristics of the firm, which were obtained from the integrated reports. The first was firm size (SIZE), which was measured as total assets, and the second was profitability (ROA), measured by return on asset, computed as income (after tax) before extraordinary item divided by total assets, while the third was BS, which was measured as number of directors constituting the board. The last was gender diversity (GEN), measured as a percentage of women in the board. Data were analysed using descriptive statistics and one-way ANOVA. The use of ANOVA was necessitated by the fact that most of the independent variables are grouped into more than two (unrelated) groups.

\section{Ethical consideration}

This article followed all ethical standards for a research without direct contact with human or animal subjects.

\section{Analysis and results Descriptive analysis}

The results in Table 1 present the descriptive statistics for the variables under study. The results indicate that the level of CED among South African mining firms is close to average. This is evidenced by the maximum score of 24 out of the obtainable 50 and a mean score of 17.88 . In comparison with the minimum and maximum values, the mean scores for SIZE and BS indicate above mid-point values. This implies that the mining firms that make up the sample are of large sizes on an average. Similarly, the mean score indicates a large BS for the sampled firms. The mean score for ROA indicates below average profitability for sampled firms. The mean score for GEN also indicates a slightly low percentage of women in the board.

Overall, there is no significant deviation from the mean scores as indicated by the value of the standard deviations.

In Table 2, the result of the CED for the sample period is as presented. The mean scores show that the level of disclosure increased between 2015 and 2016, and with a downward trend in 2017. The result shows that 2018 has the highest level of disclosure from all the years under study.

The result in Table 3 indicates the level of CED from this study alongside two previous studies at different times. First is the result of earlier studies (case 1) by Antonites and de Villiers (2003) and De villiers and Barnard (2000) covering a period from 1994 to 2001 in which the level of environmental disclosure was assessed through six self-developed environmental checklists. The percentage of disclosure with respect to each of the disclosure checklist for each year is as presented.

TABLE 1: Descriptive statistics of variables under study.

\begin{tabular}{lccccc}
\hline Variable & $\boldsymbol{N}$ & Min & Max & Mean & Standard deviation \\
\hline CED & 32 & 9 & 24 & 17.88 & 0.570 \\
Size & 32 & 1 & 3 & 1.69 & 0.693 \\
ROA & 32 & 0 & 3 & 0.72 & 0.888 \\
BS & 32 & 3 & 3 & 2.62 & 0.492 \\
GEN & 32 & 1 & 5 & 2.66 & 0.937 \\
\hline
\end{tabular}

Source: Authors' computation (2019) from the Annual Reports of Sampled Companies CED, corporate environmental disclosure; ROA, return on asset; BS, board size; GEN, gender diversity.

TABLE 2: Overall corporate environmental disclosure index on annual basis.

\begin{tabular}{lccc}
\hline Year & No of company & CED score & CED mean score \\
\hline 2015 & 8 & 133 & 16.63 \\
2016 & 8 & 147 & 18.38 \\
2017 & 8 & 138 & 17.25 \\
2018 & 8 & 154 & 19.25 \\
\hline Total & $\mathbf{3 2}$ & & \\
\hline
\end{tabular}

Source: Authors' computation (2019) from the Annual Reports of Sampled Companies CED, corporate environmental disclosure. 
TABLE 3a: Analysis on corporate environmental disclosure in the mining sector based on previous studies (case 1).

\begin{tabular}{lcccccccc}
\hline Year & 1994 & 1995 & 1996 & 1997 & 1998 & 1999 & $\mathbf{2 0 0 0}$ & 2001 \\
\hline Disclosure 1 (\%) & 13 & 13 & 42 & 39 & 28 & 48 & 34 & 36 \\
Disclosure 2 (\%) & 9 & 8 & 10 & 11 & 32 & 52 & 54 & 23 \\
Disclosure 3 (\%) & 23 & 27 & 46 & 63 & 25 & 29 & 10 & 9 \\
Disclosure 4 (\%) & 17 & 29 & 33 & 68 & 28 & 42 & 14 & 11 \\
Disclosure 5 (\%) & 12 & 20 & 36 & 52 & 57 & 60 & 66 & 64 \\
Disclosure 6 (\%) & - & - & - & - & 19 & 23 & 8 & 34 \\
\hline Total \% & $\mathbf{7 4}$ & $\mathbf{9 7}$ & $\mathbf{1 6 7}$ & $\mathbf{2 3 3}$ & $\mathbf{1 8 9}$ & $\mathbf{2 5 4}$ & $\mathbf{1 8 6}$ & $\mathbf{1 7 7}$ \\
\hline Average \% & $\mathbf{1 4 . 8}$ & $\mathbf{1 9 . 4}$ & $\mathbf{3 3 . 4}$ & $\mathbf{4 6 . 6}$ & $\mathbf{3 1 . 5}$ & $\mathbf{4 2 . 3 3}$ & $\mathbf{3 1}$ & $\mathbf{2 9 . 5}$ \\
\hline
\end{tabular}

Sources: De Villiers, C.J. \& Barnard, P., 2000, 'Environmental reporting in South Africa from 1994 to 1999: A research note', Meditari Accountancy Research 8(1), 5-23. https://do org/10.1108/10222529200000002; and, Antonites, E. \& De Villiers, C., 2003, 'Trends in South African corperats Research 11(1) 1-10. https:// doi.org/10.1108/10222529200300001

TABLE 3b: Analysis on corporate environmental disclosure in the mining sector based on later studies (case 2 ).

\begin{tabular}{lccc}
\hline Variable & $\mathbf{2 0 0 4}$ & $\mathbf{2 0 0 5}$ & $\mathbf{2 0 0 6}$ \\
\hline Max & 484 & 484 & 484 \\
Score & 174 & 186 & 241 \\
$\%$ & 35.95 & 38.43 & 49.79 \\
\hline
\end{tabular}

Sources: Adagish, K.F., 2009, 'The nature and extent of non-financial disclosure in the South African mining industry', Unpublished Master's thesis, School of Accounting Faculty of Management Studies, University of KwaZulu-Natal

TABLE 3c: Analysis on corporate environmental disclosure in the mining secto based on present studies (case 3).

\begin{tabular}{lcccc}
\hline Variable & $\mathbf{2 0 1 5}$ & $\mathbf{2 0 1 6}$ & $\mathbf{2 0 1 7}$ & $\mathbf{2 0 1 8}$ \\
\hline Max & 400 & 400 & 400 & 400 \\
Score & 133 & 147 & 138 & 154 \\
$\%$ & 33.25 & 36.75 & 34.5 & 38.5 \\
\hline
\end{tabular}

Sources: Authors' computation (2019) from the Annual Reports of Sampled Companies

Further analysis was carried out to determine the average percentage disclosure for all the years in that study. The result indicates a steady increase in CED from 1994 to 1997. After a sharp decrease in 1998, it increased again in 1999 and decreased in subsequent periods in 2000 and 2001.

Later studies (case 2) by Adagish (2009) conducted over the period 2004-2006 and assessed the CED level using 22 environmental checklists for 22 mining firms give rise to a maximum score of 484 obtainable for each year. The study shows an increase of 7\% from 2004 to 2005 and 30\% from 2005 to 2006. There is a continuous level of improvement across the sampled period.

This study (case 3) rated the level of CED using data for eight mining firms over a 4-year period (2015-2018). The maximum score obtainable by a firm from the 10 environmental indicators when using the five-point rating scale summed up to 50 . The maximum score obtainable for eight firms in a year therefore stands at 400 . The percentage of disclosure achieved for each year under study indicates some marginal increase from the period 2015 to 2018, except for the decrease in 2017. However, the results of this study indicate a low level of disclosure from 2015 to 2018. Overall, comparing the highest level of CED recorded in each of the cases, the level of reporting increased from $46.6 \%$ in case 1 (1997) to $49.79 \%$ in case 2 (2006). It decreased from $49.79 \%$ in case 2 to $38.5 \%$ in case 3 (2018), and this study still signals a low level of disclosure.

\section{Influence of corporate characteristics on the level of corporate environmental disclosure}

The mean score of 17.88 for CED is spread across the various levels of variable groupings in Table 4 . The purpose of using each of the corporate characteristics to create a group is to observe variation in the mean scores across each of the variable groupings. Codes were assigned to each variable based on the number of groupings as follows: firm size (1-4); profitability (0-3); BS (1-3); gender diversity (1-5). An analysis of the table shows that different patterns of variations in mean score are observed for all the variables. By using firm size as a basis for creating groups, the mean scores of firms differ across the four classes of firm sizes far from each other, ranging from 11.00 to 19.07. The mean score is slightly proportional to the number of observations in each category as groups with the highest observations have higher mean scores.

By using profitability as a basis for creating groups, the mean scores of firms differ across the four classes of profitability but not far from each other, ranging from 17.14 to 21.33. The mean score is not proportional to the categorisation and the number of observations in each category. Category 20\% $29 \%$, with only three observations, has a mean score higher than the other two categories; less than $0 \%$ and $0 \%-9 \%$ each with observations 15 and 14, respectively. The mean scores for BS indicate a variation that is proportional to the number of observations. The largest category of BS (11\% - 15\%), which also has the highest number of observations, has the highest mean score (19.15). Gender diversity is not proportional to the number of observations in each category. For instance, the highest mean score is 21.00 with only one observation in that category, whereas other categories with up to 14 observations have a lower mean score of 19.71 .

TABLE 4: Descriptive statistics for all the variables.

\begin{tabular}{llll}
\hline Firm characteristics & Description & $\boldsymbol{N}$ & Mean \\
\hline Firm size & $1 \mathrm{bn}-49 \mathrm{bn}$ & 14 & 18.64 \\
& $50 \mathrm{bn}-99 \mathrm{bn}$ & 14 & 19.07 \\
& $100 \mathrm{bn}-149 \mathrm{bn}$ & 2 & 11.00 \\
& $150 \mathrm{bn}-199 \mathrm{bn}$ & - & - \\
Total & - & 32 & 17.88 \\
Profitability less than & $0 \%$ & 15 & 17.87 \\
& $0 \%-9 \%$ & 14 & 17.14 \\
& $10 \%-19 \%$ & - & - \\
Total & $20 \%-29 \%$ & 3 & 21.33 \\
Board size & - & 32 & 17.88 \\
& $1-5$ & - & - \\
& $6-10$ & 12 & 15.75 \\
Total & $11-15$ & 20 & 19.15 \\
Gender & - & 32 & 17.88 \\
diversity & $0 \%-9 \%$ & 2 & 15.00 \\
& $10 \%-19 \%$ & 14 & 19.71 \\
& $20 \%-29 \%$ & 10 & 15.30 \\
& $30 \%-39 \%$ & 5 & 18.40 \\
Total & $40 \%$ and above & 1 & 21.00 \\
\hline Source: Auth & - & 32 & 17.88 \\
\hline
\end{tabular}

Source: Authors' computation (2019) from the Annual Reports of Sampled Companies bn, billion. 
The variation in the mean scores in each categorisation is a prima facie evidence of significant fluctuation in firm size and BS, which may not hold for profitability and gender diversity. Further analysis utilising parametric inferential statistics, which is intended to draw a conclusion on whether or not these happened by chance, is presented in Table 5 .

\section{Inferential statistics}

The result in Table 5 shows the statistical significance of the variation in mean scores for each of the influencing factors at different levels of categorisations.

At 5\% significance level, $p$ values establish the fact that the level of CED in the South African mining firms differs significantly based on firm size $(p=0.003<0.05)$ and BS $(p=0.039<0.05)$ but does not differ significantly on account of profitability $(p=0.366>0.05)$ and gender diversity $(p=0.142>0.05)$.

\section{Hypotheses testing}

The result of the descriptive statistics in Table 4 and the inferential statistics in Table 5 support that firms differ significantly on the level of CED on account of firm size. The alternate hypothesis $\left(\mathrm{H}_{1} 1\right)$ is therefore accepted and the null hypothesis $\left(\mathrm{H}_{0} 1\right)$ is rejected. Similarly, both the descriptive and inferential statistics support that firms differ significantly on the level of CED on account of BS. The alternative hypothesis $\left(\mathrm{H}_{1} 2\right)$ is, therefore, supported and the null hypothesis $\left(\mathrm{H}_{0} 2\right)$ is rejected. The result of the descriptive statistics in Table 4 shows that although there is variation in the mean scores for profitability and gender diversity at each categorisation, the variations are not statistically significant for both variables. Thus, alternate hypotheses $\left(\mathrm{H}_{1} 3\right)$ and $\left(\mathrm{H}_{1} 4\right)$ are rejected and null hypotheses $\left(\mathrm{H}_{0} 3\right)$ and $\left(\mathrm{H}_{0} 4\right)$ are accepted.

\section{Discussion}

The findings of this study revealed that the level of CED in the mining sector in South Africa is high. This is expected considering the perceived impact of their activities on the environment. This confirms the results of previous studies such as that by Antonites and de Villiers (2003), which revealed that a greater proportion of mining companies than top industrial companies in South Africa disclose environmental information. However, comparing the level of CED as found in the present study with those of earlier studies as presented in Table 3, adoption of IR may not have contributed or significantly influenced the level of CED in the South African mining sector. The regulatory framework guiding the practice of corporate reporting in a country affects how businesses engage in the practice and discourse of sustainability. Expectedly, with the mandatory adoption of IIRF and the King codes of corporate governance, companies should align their integrated reports more closely to disclose information on environmental issues. Instead, there is a decline compared to previous studies.

Tracing the impact of regulation on the level of CED in previous studies, Antonites and de Villiers (2003) noted that the decrease in the level of reporting in 1998 and subsequent years (2000 and 2001) could be because of lack of legal requirements in regards to the disclosure of environmental information. This has enabled companies to decide what to report as well as what the extent of the disclosure should be. The increase in the level of disclosure between 2004 and 2006 as revealed in the work of Adagish (2009) also shows the role of regulation. It was in 2004 that the JSE social responsibility index (SRI) was launched. The JSE SRI index is a reporting criterion that classifies those companies listed on the JSE which incorporated the principles of the triple bottom line on their reporting systems and places corporate governance as the basis by which the principles of the triple bottom line are initiated (JSE 2005). It is clear that the impact of regulation that has brought about the mandatory adoption of IR for JSE firms has not influenced the level of CED in the mining sector.

It is interesting to posit that the decline noticed in this study may be because of the assessment of the level of CED in terms of quality rather than quantity as done in previous studies. This approach is preferred because assessment of CED in terms of quality contributes to the quality of information disclosed in the integrated reports, and the only quality integrated report is value - relevant to investors and other stakeholders. A five-point rating scale was utilised to measure the quality of disclosure, which ranges from 1, where the item is 'just mentioned' to 5 for 'significant disclosure'. In addition, the CED checklists adopted were based on a

TABLE 5: ANOVA for corporate environmental disclosure index at different levels of firm characteristics.

\begin{tabular}{|c|c|c|c|c|c|c|c|}
\hline Statements & Varaibles & Sum of squares & $d f$ & Mean square & $\boldsymbol{F}$ & Sig & Decision \\
\hline \multirow[t]{3}{*}{ Firms differ in CED on account of variation in sizes (H1) } & Between groups & 217.357 & 2 & 108.678 & 7.327 & 0.003 & \multirow{3}{*}{$\begin{array}{l}(p<0.05) \\
\text { Supported }\end{array}$} \\
\hline & Within groups & 430.143 & 29 & 14.833 & - & - & \\
\hline & Total & 647.500 & 31 & - & - & - & \\
\hline \multirow[t]{3}{*}{ Firms differ in CED on account of variation in profitability (H2) } & Between groups & 43.386 & 2 & 21.693 & 1.041 & 0.366 & \multirow{3}{*}{$\begin{array}{l}\text { Decision: } \\
(p>0.05) \text { Not } \\
\text { supported }\end{array}$} \\
\hline & Within groups & 604.114 & 29 & 20.832 & - & - & \\
\hline & Total & 647.500 & 31 & - & - & - & \\
\hline \multirow[t]{3}{*}{ Firms differ in CED on account of variation in Board size (H3) } & Between groups & 86.700 & 1 & 86.700 & 4.638 & 0.039 & \multirow{3}{*}{$\begin{array}{l}\text { Decision } \\
(p<0.05) \\
\text { supported }\end{array}$} \\
\hline & Within groups & 560.800 & 30 & 18.693 & - & - & \\
\hline & Total & 647.500 & 31 & - & - & - & \\
\hline \multirow[t]{3}{*}{ Firms differ in CED on account of variation in gender diversity $(\mathrm{H} 4)$} & Between groups & 141.343 & 4 & 35.336 & 1.885 & 0.142 & \multirow{3}{*}{$\begin{array}{l}\text { Decision } \\
(p>0.05) \text { Not } \\
\text { supported }\end{array}$} \\
\hline & Within groups & 506.157 & 27 & 18.747 & - & - & \\
\hline & Total & 647.500 & 31 & - & - & - & \\
\hline
\end{tabular}

Source: Authors' computation (2019) from the Annual Reports of Sampled Companies

CED, corporate environmental disclosure. 
checklist covering 10 environmental performance variables derived from the GRI G4 framework. The GRI 4 is the most definitive, widely accepted and commonly-applied framework for environmental reporting globally. It follows, therefore, that the present study assessed CED in line with international best practices.

As noted in Tables 2 and 3 of this study, the current level of CED, the slight decrease in 2017 may not be unconnected with the release of the King IV in 2016, which moved away from the 'apply or explain' concept to the 'apply and explain' concept. Beginning from 2017, King IV places additional mandatory requirements with which firms are bound to comply, and this may have resulted in the low level of CED by some of the sampled mining firms. This may not apply to subsequent years because firms have more time to apply the new King IV, and this is as reflected in the increase in CED in 2018.

Apart from the inherent nature of the mining sector, which influences the level of disclosure of environmental information, this study found that firm size and BS are additional corporate characteristics that influence the level of CED in the sampled mining firms. The association between firm size and CED supports the view that large firms have more stakeholders to satisfy, who are all interested in diverse types of information and how these information types can create value. This is in line with Bhattacharyya (2014), Deegan and Gordon (1996), Ho and Taylor (2007) and Mohammed and Tamoi (2006). The firms sampled for this study may be classified as firms with averagely large BS. This is based on the raw data obtained for this study, in which the number of directors in the board ranges from eight to 13. In addition, the mean score of 2.62 for BS as indicated in Table 2 leans more towards the maximum value. This supports the view that the varied composition of the board is perceived to be capable of influencing the extent to which corporate entities disclose environmental information. This explains the association between the high level of CED and BS for this study in line with the works of Ofoegbu et al. (2018) and Trireksani and Djajadikerta (2016).

In this study, both profitability and gender diversity have no influence on the level of CED. The issue of environmental responsibility is of paramount importance in the mining sector because of the risky nature of the companies' activities on the environment (Moloi 2009). Failure in this regard will lead to greater liability for the firms. Therefore, financial performance may not likely be the motivation for engaging in this practice; it is a responsibility they owe to the society. Similarly, the board diversity policy in South Africa, in February 2018, mandated that women constitute $20 \%$ of the board of listed firms. This study shows that sampled firms only break even on this requirement. From the 32 annual reports examined, which are sourced from eight firms over a 4-year period, exactly half (16) of this number achieved the $20 \%$ benchmark. This may be the possible explanation for the lack of association between BS and CED.

\section{Conclusion}

This study examined the level of CED under the present IR approach followed by firms listed on the JSE. It sought to unbundle the variation in the level of CED on account of two corporate attributes, namely firm size and profitability, and two corporate governance characteristics, which are BS and gender diversity. Apparently, adoption of IR by firms listed on the JSE has not influenced the level of CED by mining firms in South Africa. In arriving at this conclusion, this study benchmarked the level of CED prior to the mandatory adoption of IR for all firms listed on the JSE with the level of CED under the current IR regime. Although this study found that there appears to be no improvement in the level of disclosure, so far the level of disclosure found in this study varies among entities in the mining sector. The study found that firm size and BS influence CED practices of sampled mining firms.

Based on the findings in this study, this study contributes to environmental disclosure literature in three major ways. Firstly, it pays particular attention to the relevance of IR to the level of environmental disclosure in terms of quality rather than quantity. This it does by benchmarking the level of CED in the present period of adoption of IR and prior periods. Secondly, it identifies BS as an effective corporate governance attribute in promoting environmental responsibility in the mining sector. Finally, apart from BS, in terms of theoretical contribution, the study makes additional contribution by identifying firm size as another significant contingent factor that accounts for variation in the level of CED.

In terms of practical implications, it is clear from the level of CED in this study when compared to prior periods that IR has not improved the level of environmental information disclosed by mining firms. Therefore, if greater disclosure of information is preferable to less, policy-makers and regulators should give particular attention to environmental issues by extending the minimum regulatory requirements concerning the concept of the natural capital, while not neglecting the other five capitals that make up the fundamental concepts of the IR. Taking note with respect to firm size as the influencing factor for CED, an appropriate CED index that can be used to evaluate the practice of firms of all sizes should be adopted. Also, noting that larger boards are associated with a higher level of CED, to improve the level of CED, South African firms are encouraged to have larger boards.

The main limitation of this study is the sample size, and the number of mining firms that make the top 100 JSE firms informs this. In addition, there exist a number of other corporate governance attributes and firm-based characteristics whose influence on the level of CED has not been examined in this study. Future research can examine the relevance of IR in improving the level of CED in other environmental high-impact sectors, thus increasing the sample size. The influence of other factors on the level of CED also calls for further research. 


\section{Acknowledgements Competing interests}

The authors declare that they have no financial or personal relationships that may have inappropriately influenced them in presenting this article.

\section{Authors' contributions}

O.O.I. wrote the article and analysed the data and T.M. provided key insights and reviewed the overall manuscript.

\section{Funding information}

This research received no specific grant from any funding agency in the public, commercial or not-for-profit sectors.

\section{Data availability statement}

Data sharing is not applicable to this article as no new data were created or analysed in this study.

\section{Disclaimer}

All the views expressed in this article are those of the authors and do not reflect an official position of the University of Johannesburg.

\section{References}

Adagish, K.F., 2009, 'The nature and extent of non-financial disclosure in the South African mining industry', Unpublished Master's thesis, School of Accounting Faculty of Management Studies, University of KwaZulu-Natal.

Adams, C.A., 2002, 'Internal organisational factors influencing corporate social and ethical reporting: Beyond current theorizing', Accounting, Auditing \& Accountability Journal 15(2), 223-50. https://doi.org/10.1108/09513570210418905

Akinlo, O.O. \& Iredele, O.O., 2014, 'Corporate environmental disclosures and market value of quoted companies in Nigeria', Business and Management Review 5(3), 171-184.

Andrikopoulos, A. \& Kriklani, N., 2013, 'Environmental disclosure and financial characteristics of the firm: The case of Denmark', Corporate Social Responsibility and Environmental Management 20(1), 55-64. https://doi.org/10.1002/csr.1281

Antonites, E. \& De Villiers, C.J., 2003, 'Trends in South African corporate environmental reporting: A research note', Meditari Accountancy Research 11(1), 1-10. https:// doi.org/10.1108/10222529200300001

Association of Chartered Certified Accountant (ACCA), 2015, Environmental management accounting, Think ahead, ACCA Technical Article, pp. 1-8, ACCA London.

Barth, M.E., Cahan, S.F., Chen, L. \& Venter, E.R., 2016, The economic consequences associated with integrated report quality: Early evidence from a mandatory setting, Working paper, viewed 04 September 2018, from https://doi.org/10.2139/ ssrn.2699409.

Bear, S., Rahman, N. \& Post, C., 2010, 'The impact on board diversity and gender composition on corporate social responsibility and firm reputation', Journal of Business Ethics 97(2), 207-221. https://doi.org/10.1007/s10551-010-0505-2

Bhattacharyya, A., 2014, 'Factors associated with the social and environmental reporting of Australian companies', Australasian Accounting, Business and Finance Journal 8(1), 25-50. https://doi.org/10.14453/aabfj.v8i1.3

Carels, C., Maroun, W. \& Padia, N., 2013, 'Integrated reporting in the South Africa mining sector', Corporate Ownership \& Control 11(1), 947-961. https://doi. org/10.22495/cocv11i1c11p6

Cheng, E.C.M. \& Courtenay, S.M., 2006, 'Board composition, regulatory regime and voluntary disclosure', The International Journal of Accounting 41(3), 262-289. https://doi.org/10.1016/j.intacc.2006.07.001

Daniel, D., 2006, 'AZF-Toulouse Quelle Verite'. ISBN 2-915681-30-9, Library of Congress. Control No: 2007370387(French).

Deegan, C., 2002, 'Introduction: The legitimizing effect of social and environmental disclosures: A theoretical foundation', Accounting, Auditing and Accountability Journal 15(3), 282-311. https://doi.org/10.1108/09513570210435852

Deegan, C. Gordan, B., 1996, 'A study of the Environmental Disclosure Practices of Australian Corporations', Accounting Business Research 23(3), 187-199.
Demir, V. \& Bahadir, O., 2014, 'An investigation of compliance with international financial reporting standards by listed companies in Turkey', Accounting and Management Information Systems 13(1), 4-34.

De Villiers, C., Rinaldi, L. \& Unerman, J., 2014, 'Integrated reporting: Insights, gaps and an agenda for future research', Accounting, Auditing \& Accountability Journa 27(7), 1042-1067. https://doi.org/10.1108/AAAJ-06-2014-1736

De Villiers, C.J. \& Barnard, P., 2000, 'Environmental reporting in South Africa from 1994 to 1999: A research note', Meditari Accountancy Research 8(1), 5-23. https://doi.org/10.1108/10222529200000002

Dube, S. \& Maroun, W., 2017, 'Corporate social responsibility reporting by South African mining companies: Evidence of legitimacy theory', South African Journal of Business Management 48(1), 23-34. https://doi.org/10.4102/sajbm.v48i1.17

Ernst \& Young, 2018, Excellence in integrated reporting awards 2018: A survey of integrated reports from South Africa's top 100 JSE-listed companies and top 10 state-owned companies, Ernst \& Young, Johannesburg.

Forum for the Future, 2009, Social banking, viewed 15 May 2019, from https://www. social-banking.org/fileadmin/isb/Artikel_und_Studien/Rethinking_Capital_ June09_Forum_for_the_future.pdf.

Global Reporting Initiative (GRI), 2013a, G4 sector disclosure for financial services, viewed 13 August 2018, from https://www.globalreporting.org/resourcelibrary/ GRI-G4-Financial-Services-Sector-Disclosures.pdf.

Global Reporting Initiative (GRI), 2013b, G4 sustainability reporting guidelines, viewed 13 August 2018, from https://www.globalreporting.org/resourcelibrary/GRIG4Part1-Reporting-Principles-and-Standard-Disclosures.pdf.

Gray, R., 2002, 'The social accounting project and accounting organization and society: Privileging engagement imaginings, new accountings and pragmatism over
critique?', Accounting Organization and Society 27(7), 687-708. https://doi. critique?', Accounting Organization and
org/10.1016/S0361-3682(00)00003-9

Gray, R.H., Kouhy, R. \& Lavers, S., 1995, 'Corporate social and environmental reporting: A review of the literature and a longitudinal study of UK disclosure', Accounting, Auditing and Accountability Journal 8(2), 47-77. https://doi.org/10.1108/09513579510146996

Hindley, T. \& Buys, P.W., 2012, 'Integrated reporting compliance with the global reporting initiative framework: An analysis of the South African mining industry', International Business \& Economics Research Journal 11(11), 1249-1260. https:// doi.org/10.19030/iber.v11i11.7372

Ho, L.J. \& Taylor, M.E., 2007, 'An empirical analysis of triple bottom line reporting and its determinants: Evidence from the United States \& Japan', Journal of International Management \& Accounting 18(2), 123-150. https://doi.org/10.1111/j.1467646X.2007.01010.x

Institute of Directors, South Africa (IOD), 1994, King IV report on corporate governance for South Africa, The Institute of Directors in South Africa NPC, Johannesburg.

Institute of Directors, South Africa (IoD), 2002, King IV report on corporate governance for South Africa, The Institute of Directors in South Africa NPC, Johannesburg.

Institute of Directors, South Africa (IoD), 2009, King IV report on corporate governance for South Africa, The Institute of Directors in South Africa NPC, Johannesburg.

Institute of Directors, South Africa (IOD), 2016, King IV report on corporate governance for South Africa, The Institute of Directors in South Africa NPC, Johannesburg.

International Energy Agency (IEA), 2015, Each country's share of CO2 emissions, viewed 15 May 2019, from https://www.ucsusa.org/global-warming/scienceand-impacts/science/each-countrys-share-of-co2.html\#.W7Kn7WgzZPY.

International Integrated Reporting Council (IIRC), 2013a, The international integrated reporting framework, viewed 05 September 2018, from https://integrated reporting.org/wp-content/uploads/2013/12/13-12-08-the-international-irframework-2-1.pdf.

International Integrated Reporting Council (IIRC), 2013b, Capital background paper for integrated reporting, viewed 05 September 2018, from https:// integratedreporting.org/wp-content/uploads/2013/03/IR-Background-PaperCapitals.pdf.

International Organization of Supreme Audit Institutions (INTOSAI), 2013 Sustainability reporting: Concepts, frameworks and the role of supreme audit institutions, Working group on environmental auditing (WGEA), INTOSAI, Vienna.

Johannesburg Securities Exchange (JSE), 2005, SRI index: Background and selection criteria, JSE Ltd, Johannesburg

Lipton, M. \& Lorsch, J.W., 1992, 'A modest proposal for improved corporate governance', Business Lawyer 48(1), 59-77.

Maguire, M., 2011, The future of corporate social responsibility reporting. The Frederick S. Pardee Center for the Study of the Longer-range Future, viewed 15 May 2019, from https://www.bu.edu/pardee/files/2011/01/PardeellB-019Jan-2011.pdf.

Melloni, G., Caglio, A. \& Perego, P., 2017, 'Saying more with less? Disclosure conciseness, completeness, and balance in integrated reports', Journal of Accounting and Public Policy 36(3), 220-238. https://doi.org/10.1016/j.jaccpubpol.2017.03.001

Mineral Council of South Africa, 2019, Mining in South Africa, viewed 28 May 2019, from https://www.mineralscouncil.org.za/sa-mining.

Mishari, M.A. \& Abdullah, M.A., 2014, 'Firm-specific characteristics and corporate financial disclosure: Evidence from an emerging market', International Journal of Accounting and Taxation 2(3), 55-78. https://doi.org/10.15640/ijat.v2n3a4

Mohammed, T.Y. \& Tamoi, G.J., 2006, 'A study of social accounting disclosure in the annual reports of Nigerian companies', Asian Journal of Business Management 3(3), 145-15.

Moloi, T., 2009, 'Assessment of corporate governance reporting in the annual report of South African listed companies', Master's dissertation, University of South Africa, Pretoria, South Africa. 
Organization of Petroleum Exporting Countries (OPEC), 2017, Nigeria facts and figures, viewed 03 March 2019, from https://www.opec.org/opec_web/en/about_us/167.htm.

Ofoegbu, G.N., Odoemelam, N. \& Okafor, R.G., 2018, 'Corporate board characteristics and environmental disclosure quantity: Evidence from South Africa (integrated reporting) and Nigeria (traditional reporting)', Cogent Business \& Management 5(1551510), 1-27. https://doi.org/10.1080/23311975.2018.1551510

Owen, D., 2008, 'Chronicles of wasted time? A personal reflection on the current state of, and future prospects for social and environmental accounting research' Accounting, Auditing and Accountability Journal 21(2), 240-267. https://doi org/10.1108/09513570810854428

Parker, L.D., 2005, 'Social and environmental accountability research: A view from the commentary box', Accounting Auditing and Accountability Journal 18(6), 842-860. https://doi.org/10.1108/09513570510627739

Shaw, W., 2012, Will emerging economies repeat the mistakes of their rich cousins, International Economic Bulletin, viewed from, http://carnegieendowment org/2012/03/01/will-emerging-economies-repeat-environmental-mistakes-oforg/2012/03/01/will-eme

Trireksani, T. \& Djajadikerta, H.G., 2016, 'Corporate governance and environmental disclosure in the Indonesian mining industry', Australasian Accounting, Business and Finance Journal 10(1), 18-28. https://doi.org/10.14453/aabfj.v10i1.3
Unerman, J., Bebbington, J. \& O'Dwyer, B., 2007, Sustainability accounting and accountability, Routledge, London. ISBN-10: 0415384885 (hbk).

United Nations (UN), 2018, About the sustainable development goals, viewed 02 November 2018, from www.un.org/sustainabledevelopment/sustainabledevelopment-goals/.

Wallace, R.S. \& Naser, K., 1995, 'Firm specific determinants of the comprehensiveness of mandatory disclosure in the corporate annual reports of firms listed on the stock exchange of Hong Kong', Journal of Accounting \& Public Policy 14(4), 311-368. https://doi.org/10.1016/0278-4254(95)00042-9

World Business Council on Sustainable Development (WBCSD), 2014, Integrated reporting in South Africa: From concept to practice, Future Leaders Programme, Maison de la Paix, Geneve.

World Steel Association, 2018, World steel in figures 2018, viewed 20 May 2019, from https://www.worldsteel.org/en/dam/jcr:f9359dff-9546-4d6b-bed099620 1185b12/World+Steel+in+Figures+2018. pdf.

Zyl, A.V., 2013, 'Sustainability and integrated reporting in the South African corporate sector', International Business \& Economics Research Journal 12(8), 903-926. https://doi.org/10.19030/iber.v12i8.7988 


\section{Appendix 1}

BOX 1-A1: List of sampled mining companies.

\begin{tabular}{l|} 
Glencore Plc \\
Anglo American Plc \\
Anglo American Platinum \\
AngloGold Ashanti Limited \\
Gold Fields Ltd \\
Sibanye Gold Ltd \\
Northam Platinum Limited \\
Impala Platinum Limited \\
\hline
\end{tabular}

Source: Johannesburg Stock Exchange

Item

\section{Materials}

Does the company report on the renewable and non-renewable materials used to produce and/or package products and services?

\section{Energy}

Are the impacts of entity's operation on energy reported and contextualised? Was amount expended on remedying damages caused by dissipation of energy reported? What is the amount of reductions in energy consumption achieved as a direct result of conservation and efficiency initiatives? Water

Does the company report the extent of its water usage? Is the impact of the entity's operation on water reported and contextualised? Was amount expended on remedying damages caused by water contamination reported? Any report on the volume of water recycled and reused?

\section{Biodiversity}

Does the company report on its impact on biodiversity? Does it have any policies or processes to reduce its impact on biodiversity? Report on whether partnerships exist with third parties to protect or restore habitat?

\section{Emissions, effluents and waste}

Are the impacts of entity's operation on greenhouse gas (GHG) emissions, effluents and waste reported and contextualised? Does the company have any measurable targets or policies for reduction?

Products and services

Does the company report on how environmental impacts of the company's products and services have been mitigated during the per iod? Are the firm's products and services environmentally compliant?

\section{Compliance}

Does the organisation provide a statement stating its compliance and/or non-compliance with environmental laws?; does the organisation report on any fines or fees associated with noncompliance? Was payment for non-compliance with environmental laws disclosed? Were instances of flaunting environmental laws and/or prosecution reported?

\section{Transport}

Does the company report environmental impacts of transporting products of the company and initiatives to reduce such impact

Supplier environmental assessment

Does the company report the use of any specific environmental criteria in the selection process of its suppliers? Does it report the percentage of new suppliers that were screened using environmental criteria

Environmental grievance mechanism

Does the firm have a mechanism in place where the impact of its operation on the environment is reported? Does the report disclose the total number of grievances about environmental impacts filed through formal grievance mechanisms during the reporting period? Did the report disclose the number of, or instances of externalities reported through its environmental grievance mechanism?

Source: Global Reporting Initiative (GRI), 2013a, G4 sector disclosure for financial services, viewed 13 August 2018, from https://www.globalreporting.org/resourcelibrary/GRI-G4-FinancialServices-Sector-Disclosures.pdf; and, Global Reporting Initiative (GRI), 2013b, G4 sustainability reporting guidelines, viewed 13 August 2018, from https://www.globalreporting.org/resourcelibrary/ GRIG4-Part1-Reporting-Principles-and-Standard-Disclosures.pdf

FIGURE 1-A1: Corporate environmental disclosure checklist.

\section{TABLE 1-A1: Likert scale scores and interpretation for corporate environmental disclosure index.}

No disclosure - The subject is not mentioned in the report at all

Just mentioned - The subject is only mentioned briefly in the report with no context provided

Disclosure to a less extent - The subject is only mentioned briefly in the report (which might include measured results) with little context provided

Disclosure to a moderate extent - The subject and measured results are discussed and a measurable target is provided for the current and/or future

0

Disclosure to a large extent - The current year performance on the subject is discussed against the target and mitigation is provided to improve performance

Significant disclosure - Full integration is achieved by linking the risk, target and mitigation with the financial aspects on the subject 